\title{
Me-DLC 皮膜の開発
}

\author{
仲 川政 宏*, 鈴 木 秀 明* \\ *(陎)イ・シイ・エス（干322-0603＼cjkstart杤木県上都賀郡西方町大字本郷 623）
}

\section{Development of Me-DLC Coatings}

Masahiro NAKAGAWA* and Hideaki SUZUKI*

*ICS Corporation (623, Hongou, Nishikata-cho, Kamitsuga-gun, Tochigi 322-0603)

Key Words : Me-DLC, UBM, Wear Resistance, Friction Coefficient, Hardness

\section{1. はじめに}

金属含有非晶質 (Me-DLC/DLC) 皮膜において，その実用 化に当たっては, 皮膜がもつ特性を十分把握し, 相手材料や 周囲の環境・使用条件に合わせて設計し，皮膜が持つ機能を 適材適所に十分発揮させることが重要である。そのためには 設計に役立つ皮膜特性データの蓄積が必須である。そこで, 特に無潤滑や境界潤滑状態に打ける低摩擦係数・耐摩耗性 (相手攻撃性を含む) と密着性に注目し, 成膜パラメータリン グにより最適化を行い, Me-DLC(DLCも含む)皮膜開発を 行った。本稿では, Me-DLC 開発皮膜と一般的な表面改質 の一つである硬質 $\mathrm{Cr}$ めっ皮膜との硬さ, 密着性, 耐焼付 き性, 摩擦係数, 耐摩耗性などの特性を調べ比較検討した。 要求特性に合った皮膜を選定し，その一部の皮膜が実部品に コーティングされて耐久性確認中のものも含め実用化された 用途について紹介する。

\section{Me-DLC の特徵}

特徵としては，スパッターリングを用いた低温成膜処理が

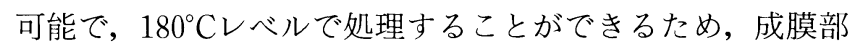
品の処理歪みを極小に押さえることが可能である。そのため, 焼戻し温度が低いSCM 材, SNCM 材, SUJ 材, SK 材, $\mathrm{SKS}$ 材, SC 材, SUS 材，Al 合金などの基材に対しても， 処理により軟化することなく使用が可能である1)。適度に金 属あるいは金属炭化物含有量を調整し, Me-DLCあるいは DLC を作製することにより特徵のある皮膜特性が得られる。

\section{ICS における Me-DLC 成膜方法}

\section{1 成膜装置}

弊社は非平衡スパッターリング (UBM) 方式の Me-DLC 成膜装置を使用している。図 1 (a) (b)に成膜および装置の 概念図を示す。この装置の特徵は, 基材と Me-DLC 膜との 密着性を向上させるために Cr ターゲットと, 金属・炭化物 を含有させるための WC ターゲットを設け，アルゴンとア セチレン混合ガス中で非平衡マグネトロンによりスパッター リングし，金属・炭化物を含有する非晶質炭素を成膜するこ

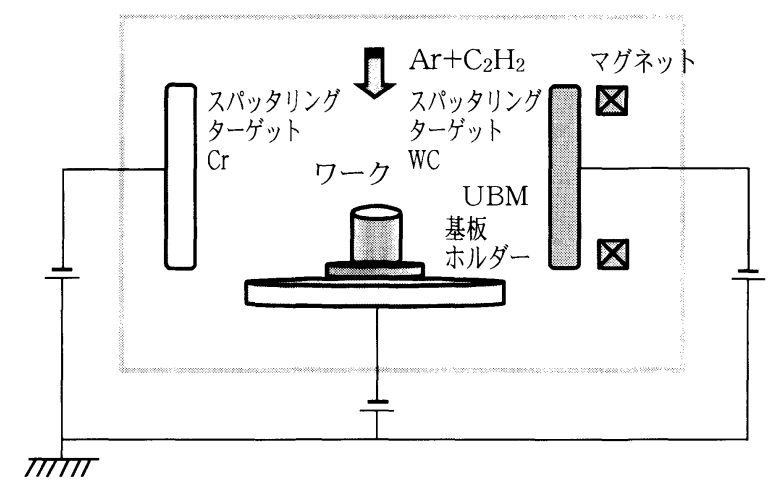

(a) Me-DLC成膜概念図

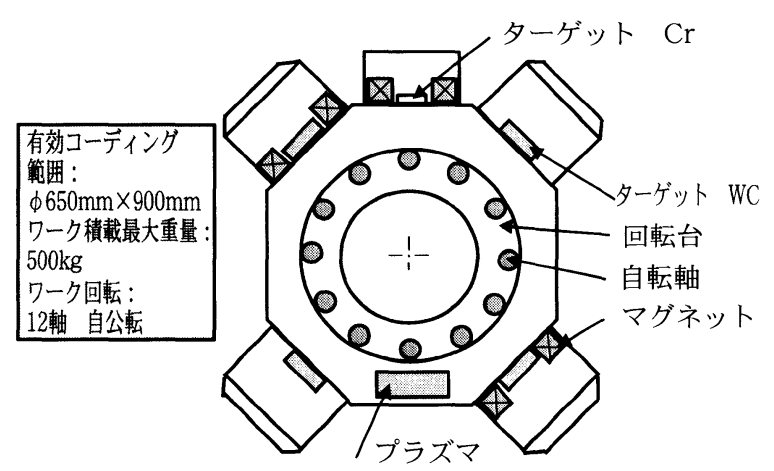

(b) Me-DLC装置概念図

図 1 Me-DLC 成膜装置概念図

とである。有効成膜範囲は $\phi 650 \mathrm{~mm} \times 900 \mathrm{~mm}$ で, ワーク の最大積載重量は $500 \mathrm{~kg}$ である。ワークの回転については 公転軸に 12 本の自転軸を有している。

また，Crターゲットを使用し窒素ガスを導入させて，ス パッタリングにより $\mathrm{Cr}-\mathrm{N}$ 系皮膜のコーティングも可能であ る。

\section{2 成膜工程}

成膜工程は，(1)ワークをターゲットに面するように設置， (2)排気・真空加熱, (3)イオンエッチングによるワーク基材の クリーニング, (4)中間層 $(\mathrm{Cr})$ をス゚ッタリングにより形成, (5)傾斜層 $\mathrm{Cr} / \mathrm{WC}$ を形成, (6)アセチレンガスを加えて, WC 

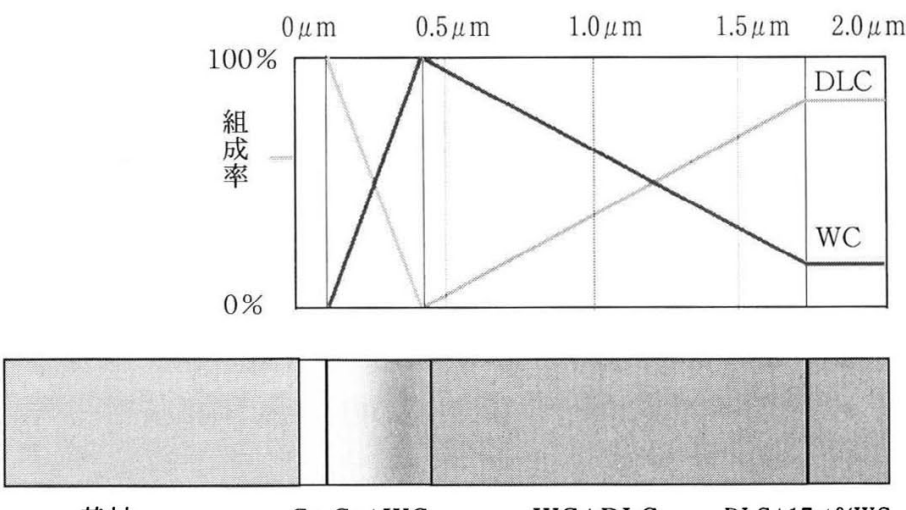

基材

$\mathrm{Cr} \mathrm{Cr}+\mathrm{WC}$

WC+DLC

DLC+17at\%WC

図 2 Me-DLC 皮膜構成概念図

表 $1 \mathrm{Me}$-DLC/DLC 成膜条件

\begin{tabular}{l|c|c|c|c}
\hline \multicolumn{1}{c|}{ 皮膜材質 } & Me-DLC-70 L 5 & Me-DLC-10 & DLC-7 & DLC-1 \\
\hline ターゲット & $\mathrm{WC}$ & $\mathrm{WC}$ & なし & なし \\
\hline 電カ & $2 \times 5.8 \mathrm{~kW}$ & $2 \times 5.8 \mathrm{~kW}$ & $0 \mathrm{~kW}$ & $0 \mathrm{~kW}$ \\
\hline マグネトロン電流 & 高電流 & 低電流 & 高電流 & 低電流 \\
\hline バイアス電圧 & 高電圧 & 低電圧 & 高電圧 & 低電圧 \\
\hline スパッターガス & $\mathrm{Ar}+\mathrm{C}_{2} \mathrm{H}_{2}$ & $\mathrm{Ar}+\mathrm{C}_{2} \mathrm{H}_{2}$ & $\mathrm{C}_{2} \mathrm{H}_{2}$ & $\mathrm{C}_{2} \mathrm{H}_{2}$ \\
\hline スパッター圧 & $\sim 0.3 \mathrm{~Pa}$ & $\sim 0.3 \mathrm{~Pa}$ & $\sim 0.3 \mathrm{~Pa}$ & $\sim 0.3 \mathrm{~Pa}$ \\
\hline $\begin{array}{l}\mathrm{C}_{2} \mathrm{H}_{2} /\left(\mathrm{C}_{2} \mathrm{H}_{2}+\mathrm{Ar}\right) \\
\text { 比率 }\end{array}$ & $20 \sim 50 \%$ & $20 \sim 50 \%$ & $100 \% \quad \mathrm{Ar} 0 \%$ & $100 \% \quad \mathrm{Ar} 0 \%$ \\
\hline
\end{tabular}

とDLCの傾斜層を形成，(7)アセチレンガスとアルゴンガス 流量を一定に保ち目標の WC/DLC 成分比率になるように一 定時間保持することである。その結果, 図 2 に示す $\mathrm{Me}$ DLCの皮膜構成となる。

\section{3 成膜パラメータ}

Me-DLC 成膜の制御用パラメータについては, プラズマ 電流, カソード電圧, 基材バイアス電圧, 炉内厈力, ガス流 量 $\left(\mathrm{Ar} / \mathrm{C}_{2} \mathrm{H}_{2}\right)$ ，基材温度などがある。

\section{Me-DLC 成膜条件と供試材}

開発する膜質としては Me-DLC 系と Me 含有量を零にし た DLC 系皮膜作製を狙い, 成膜パラメータを変えて実験計 画法により検討した。その中の典型的な Me-DLC/DLC 皮 膜をそれぞれ 2 種類を選び評価に供した。それらの成膜パラ メータを表 1 に示す。

基材は SKD 11 の焼入れ焼戻し材を用い，基材の硬さは HRC (150 kgf) 61.6 とした。硬さ試験とスクラッチ試験用の 試験片形状は $\phi 30 \mathrm{~mm} \times 5 \mathrm{~mm}$, 摩擦摩耗試験用の形状は ф $55 \mathrm{~mm} \times 6 \mathrm{~mm}$ である。

皮膜特性の比較材として, SKD 11 焼入れ焼戻し材に 10 $\mu \mathrm{m}$ の硬質 $\mathrm{Cr}$ めっきを施した試験片を用いた。

\section{Me-DLC 皮膜特性}

\section{5. $1 \mathrm{Me}(\mathrm{WC})-\mathrm{DLC} / \mathrm{DLC}$ 皮膜の構成}

ダイアモンド結晶構造 $\mathrm{sp}^{3}$ とグラファイト結晶構造 $\mathrm{sp}^{2}$ 以 外のあらゆる非晶質構造の炭素はダイアモンド状炭素 (a-C) と呼ばれ,さらに水素と結合した非晶質構造の炭素, すなわ
ちアモルファス水素化炭素 $(\mathrm{a}-\mathrm{C}: \mathrm{H})$ も含め広く $\mathrm{DLC}$ と呼 ばれている ${ }^{2), 3)}$ 。C $\mathrm{sp}^{3}-\mathrm{C} \mathrm{sp} \mathrm{sp}^{2}-\mathrm{H}$ の 3 元系状態図内に位置す るすべてが DLCに属することになる。そのため硬いダイア モンドに近い構造の非晶質状のものから, 軟らかく滑りやす いグラファイトに近い構造の非晶質状のものや高分子材料に 近い炭化水素まで含まれるので, 皮膜の成分分析・構造解析 と皮膜特性を把握することが重要である。

WC-DLCの皮膜は金属 Wまたは炭化タングステン WC のナノメータレベルの微小な粒子がアモルファス水素化炭素 $\mathrm{a}-\mathrm{C} ： \mathrm{H}$ マトリックス中に存在する ${ }^{4), 5)}$ 。

Me-DLC-10 と DLC- 1 皮膜についてのラマンスペクトル の解析を行った。この結果はそれぞれダイアモンドとグラ ファイトに特有な結晶ピークは現れず, 非晶質炭素のパター ンが示された。なお，Me-DLC-10においては $800 \mathrm{~cm}^{-1}$ 付近 にWCを含有する WC-DLC 特有の鋭いピーク ${ }^{6}$ が示された。

\section{2 皮膜硬さ}

膜厚 $3 \mu \mathrm{m}$ コーティングした硬さ試験片を用いて，皮膜硬 さをビッカース硬さ計により荷重 25 grf で計測した。その 結果を図 3 に示すが, Me-DLC-70 L 5 は HV 2000, MeDLC-10 は HV 1400 が得られた。これはバイアス電圧の差 により皮膜構造・構成が変わり硬さの差になったものと思わ れる。DLC-7 は HV 2000, DLC-1 は HV 1000 の硬さを示し た。これは $\mathrm{C}_{2} \mathrm{H}_{2}$ の流量の差が皮膜構造を変え硬さの差に なったものと思われる。

\section{3 皮膜の密着性}

皮膜の密着性についての計測はスクラッチ試験機 (CSEM Revetest)を用いた。上記硬さ試験片を用いて負荷速度 100 
皮膜硬さ

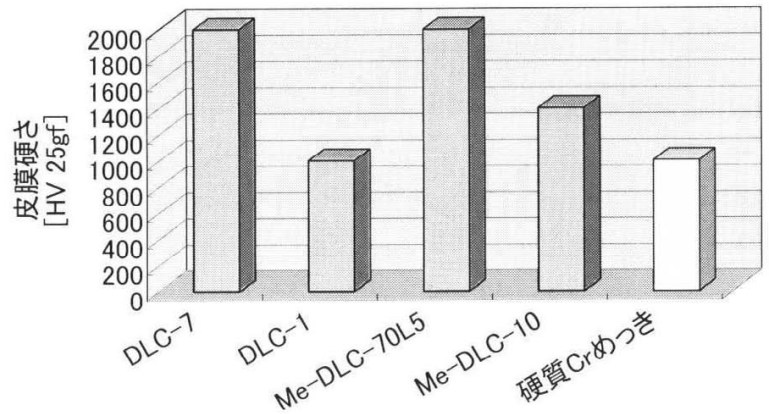

図 3 皮膜のビッカース硬さ 荷重 $25 \mathrm{gf}$

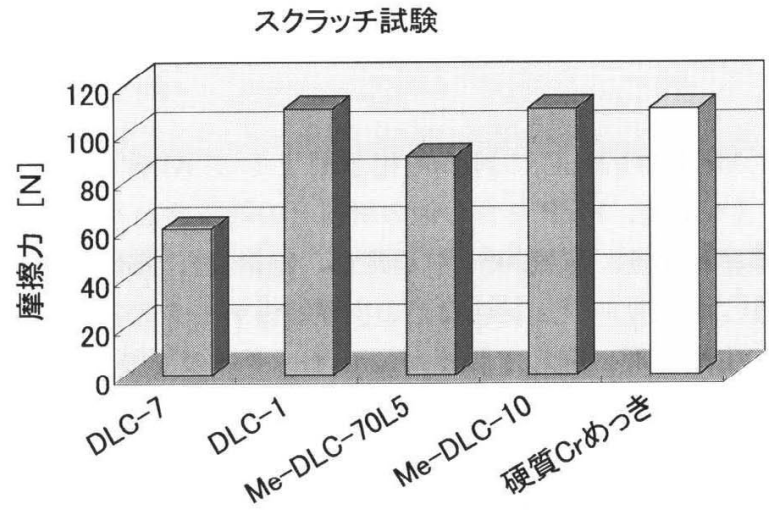

図 4 皮膜の密着性

スクラッチ試験により皮膜がはく離した時の摩擦力を示 寸

$\mathrm{N} / \mathrm{min}$ ，テーブル速度 $10 \mathrm{~mm} / \mathrm{min}$ で行い，いずれもはく離 が発生する時の摩擦力で求めた。その結果を図 4 に示す, Me-DLC-70 L 5 が摩擦力 90 N, Me-DLC-10 が摩擦力 $110 \mathrm{~N}$ となった。また DLC-7 は摩擦力 $60 \mathrm{~N}$, DLC-1 は摩擦力 110 Nである。

\section{4 油塗布耐焼付き性}

機械構造部品に扔ける境界潤滑状態での厳しい使用条件を 想定し，皮膜の油塗布耐焼付き性評価試験を行った。試験に 当たっては高千穂精機社製摩擦摩耗試験機を改良しボールオ ンディスク試験で焼付き限界荷重を測定した。試験条件は,

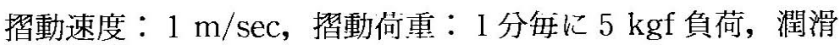
油：エンジン油 5 W-30 とし，材料の組み合わせはボール 材： $\phi 8 \mathrm{~mm} \mathrm{SUJ} 2 \mathrm{HV}(0.5 \mathrm{kgf}) 850$, ディスク材： $\mathrm{SKD} 11+$ 皮膜(膜厚 $2 \sim 3 \mu \mathrm{m}$ ) とし，ディスク面粗度： Ra 0.03 で行った。

その結果を図 5 に示す。耐焼付き性は，DLC-7 が硬質 $\mathrm{Cr}$ めっきより優れ，Me-DLC-70 L 5 は硬質 Cr めっきと同等の 值を示した。いずれも皮膜硬さが HV 2000 あり耐焼付き性 に有利に働いたものと思われる。一方 DLC-1 と Me-DLC-10 はSKD 11 材と比べ 3 倍の焼付き限界荷重を示した。

\section{5 無潤滑動摩擦係数}

上記高・下穂精機社製ポールオンディスク試験により，下記 の条件で動摩擦係数を計測した。材料の組み合わせは，ボー ル材: $\phi 8 \mathrm{~mm}$ SUJ 2 HV (0.5 kgf) 850, ディスク材：
油塗布焼付き試験 $1 \mathrm{~m} / \mathrm{sec}$

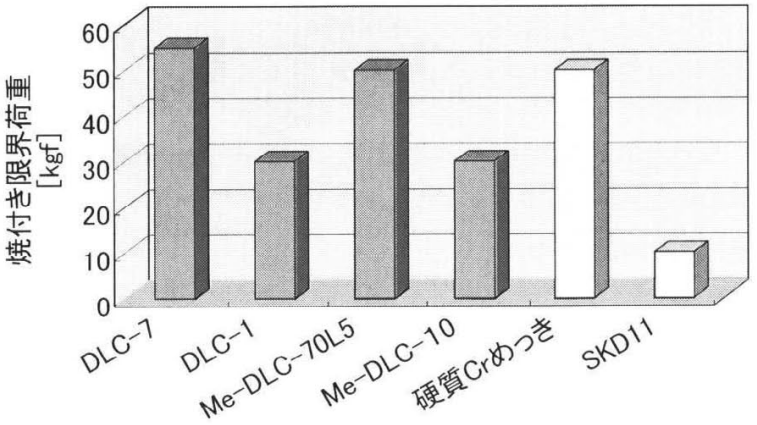

図 5 油塗倾皮膜の耐烍付き性

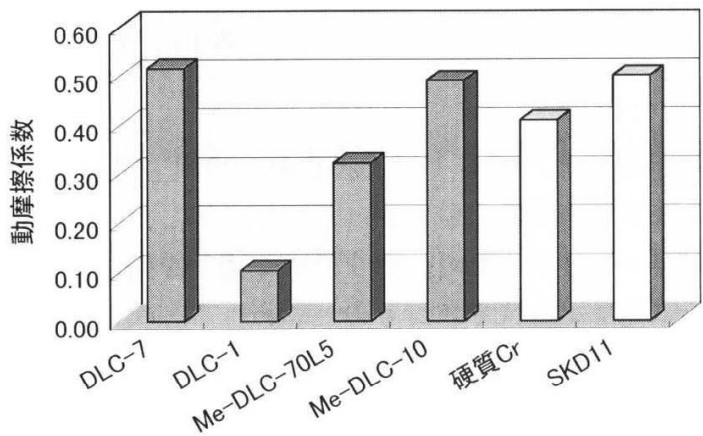

(a) 無潤滑摩擦係数

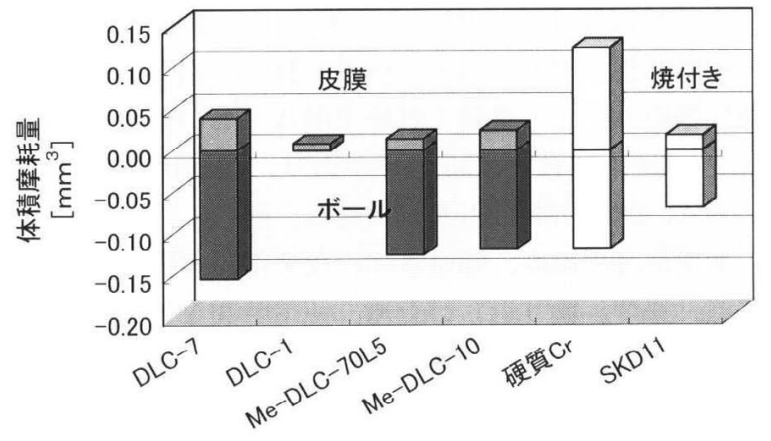

（b）無潤滑における皮膜摩擦と相手攻撃性

図 6 ボールオンディスクによる無潤滑摩擦摩耗特性 （荷重 $30 \mathrm{kgf}, 155 \mathrm{~mm} / \mathrm{s}$ )

$\mathrm{SKD} 11+$ 皮膜 (膜厚 $2 \sim 3 \mu \mathrm{m}$ )，ディスク面粗度：Ra 0.03 とした。試験条件は，摺動速度：155 mm/s，摺動荷重：30 $\mathrm{kgl}$, 潤滑：なしで行い, 動摩擦係数は摺動距離 $38.8 \mathrm{~m}$ の 時点で計測した。その結果を図 6 (a)に示す。その結果，無 潤滑動摩擦係数は DLC.1 が 0.1 と一番低く, 次に Me-DLC70 L 5 が 0.32 と低い值を示した。

\section{6 無潤滑耐摩耗性}

5.5 と同じ条件で挧動距離 $77.6 \mathrm{~m}$ 時点の皮膜の体積摩耗 量と相手材の体積摩耗量を計測した。皮膜の摩耗量は表百粗 さ計により摩耗した断面積を求め,ディスクの軌道円楇距離 を掛け摩耗体積とした。一方，相手のボールの摩耗量は損耗 した部分の摩耗半径から体積を計算により求め相手攻撃性の 尺度とした。その結果を図6(b)に示す。 
表 2 Me-DLC/DLC 皮膜の応用

\begin{tabular}{|c|c|c|c|c|}
\hline 産業分野 & \multicolumn{2}{|c|}{ 用 途 } & 皮膜材質 & 備 \\
\hline \multirow[t]{4}{*}{ 自動車 } & \multicolumn{2}{|c|}{$\begin{array}{l}\text { ピストン } \\
\text { ピストンピン }\end{array}$} & $\begin{array}{l}\mathrm{Cr} / \mathrm{DLC} \\
\text { WC-DLC/DLC }\end{array}$ & 産業用自動車 \\
\hline & \multicolumn{2}{|c|}{$\begin{array}{l}\text { ディーゼル用燃料噴射ポンプ } \\
\text { ローラ } \\
\text { プランジャー } \\
\text { ベーン }\end{array}$} & $\begin{array}{l}\text { WC-DLC/DLC } \\
\text { WC-DLC/DLC } \\
\mathrm{Cr} / \mathrm{DLC}\end{array}$ & \\
\hline & 動弁系部品 & $\begin{array}{l}\text { バルブ } \\
\text { カム } \\
\text { バルブリフタ- } \\
\text { ロッカーアーム }\end{array}$ & $\begin{array}{l}\mathrm{Cr} / \text { WC-DLC } \\
\mathrm{Cr} / \mathrm{DLC} \\
\mathrm{Cr} / \text { WC-DLC } \\
\text { WC-DLC/DLC }\end{array}$ & トラック， ある種の乗用車 \\
\hline & \multicolumn{2}{|l|}{ ドアロック } & WC-DLC/DLC & \\
\hline \multirow[t]{3}{*}{ 産業機械 } & \multicolumn{2}{|l|}{ ベアリング } & $\mathrm{Cr} / \mathrm{WC}-\mathrm{DLC}$ & 特殊ベアリング (転動, 替動) \\
\hline & \multicolumn{2}{|l|}{ 繊維機械 } & $\mathrm{Cr} / \mathrm{WC}-\mathrm{DLC}$ & \\
\hline & \multicolumn{2}{|l|}{ 押出し金型 } & $\mathrm{Cr} / \mathrm{WC}-\mathrm{DLC}$ & \\
\hline
\end{tabular}

評価結果は，DLC-1 が皮膜自身の摩耗は少なく，且つ相 手攻撃性が一番低く最も優れた特性を示した。これは動摩擦 係数が 0.1 と低いため，滑りやすく相手を傷つけずにお互い に低摩耗量を維持できたものと思われる。次に皮膜の摩耗が 少ないのはMe-DLC-70 L 5 であるが，この皮膜も動摩擦係 数は 0.32 と 2 番目に低いが, 硬さが高いため相手攻撃性が ある。Me-DLC-10 は密着性が優れ, 無潤滑において摩擦係 数が比較的低く良好である。Me-DLC-70 L 5 は油潤滑で耐 摩耗性と耐焼付き性が良好である。

以上の検討により，DLC-1 は密着性に優れ，無潤滑にお いて耐摩耗性が他のものと比べ最も良く，相手攻撃が少なく， 摩擦係数が 0.1 と一番低く良好であることが分かった。次に DLC-7 は硬さが HV 2000 レベルあり，潤滑状態での耐摩耗 性が良く，耐焼付き性も良好である。但し，適用に当たって は, 使用部品の温度, 潤滑状態, 相手部品材料, 荷重・負荷 の状態, 速度, 繰り返しの有無, 使用時間などを考慮して, 最適な皮膜を選定する必要がある。

\section{6. 用途開発}

初期から樹脂金型， $\mathrm{Al}$ 合金用切削工具， $\mathrm{Al}$ 合金や $\mathrm{Ni}$ 合 金用鍛造工具，フェライト，アルミナ，超硬合金用粉末成形 工具, 押出し金型, 繊維機械部品, 油圧機器部品などに Me-DLC/DLCが使用されている。また，潤滑状態が厳しい 電気製品においては, 耐摩耗性, 耐焼付き性が要求される。 複写機, ファクシミリ, エアコン, 扇風機, 洗濯機, モータ, ポンプなどの回転部や霄動部に応用が検討されている。

現在，Me-DLC/DLCの適用中および実用化中の機械構造 部品などの用途例を表 2 に示す7)。

\section{7. 今後の課題}

これから手掛けるべき課題としては,
(1) Me-DLC/DLCに対して相手材として Al 合金，Mg 合 金, $\mathrm{Cu}$ 合金, FRP を含む他の材料との組み合わせにおける 摩擦摩耗特性, 電気的特性 (導電性, 絶縁性), 熱伝導率, 耐 食性, 耐エロージョン性などの皮膜特性デー夕の蓄積。

（2）生産管理に関して膜厚が $\mu \mathrm{m}$ オーダーの皮膜の簡単で, 速く, 安価な成分分析や構造解析方法の確立が挙げられる。

\section{8. おわりに}

Me-DLC/DLC の成膜において，成膜パラメー夕を変える ことにより，特徵のある摩擦摩耗特性が得られた。皮膜の適 用に当たっては，対象部品の使用環境条件を把握し，部品設 計する側とコーティング施工する側とが良く摺合わせをして 皮膜の特性を生かした設計が重要である。皮膜成分・構造が 解明され，皮膜特性のデータがさらに充実されることにより， 適用部品の設計がし易くなり，益々，用途が広がるものと期 待できる。

(2002-9-2 受理)

\section{文献}

1）池永 勝, 鈴木秀人；超硬質皮膜の原理と工業的応用, p. 14 (日刊工業新聞社, 2002)

2 ) J. Robertson ; Phys. stat, Sol. (a), 186, No. 2, 177 (2001)

3 ) 斎藤秀俊; 表面技術協会 材料機能ドライプロセス部会第 50 回例会資料, p. 2(2002)

4 ) C. Strondl ; Surface and Coating Technology, 142-144 (2001)

5 ) C. Strondl ; Mechanical and Tribological properties of Metal Containing Diamond Like Carbon Coatings (Me-DLC) Deposited Under Different Plasma Confinement Conditions

6 ）仲川政宏；表面技術協会 材料機能ドライプロセス部会第 50 回例会資料（2002）

7 ) Hauzer 社技術資料 